\title{
Income Inequality and Public Debt: What Can Be Learned from the Lebanese Indebtedness?
}

\author{
Adham Sayed (Corresponding author) \\ Ph.D. Huazhong University of Science and Technology, School of Economics, Wuhan, China \\ Tel: 86-131-2512-3102Ｅ-mail: sadham@hust.edu.cn
}

Received: October 22, 2020 Accepted: November 9, 2020 Published: November 16, 2020

doi:10.5296/ber.v10i4.17856 URL: https://doi.org/10.5296/ber.v10i4.17856

\begin{abstract}
This paper examines the impact of domestic public debt on income inequality in Lebanon. The analysis is carried out using the Autoregressive Distributed Lag (ARDL) approach and Error Correction Model (ECM). The data used covers the period between 1990 and 2015. By applying the bounds test, we indicate that there is the existence of a long-run relationship between our variables. Therefore, in both the short and long run, our results show that the domestic share of public debt has a positive and significant effect on income inequality. Hence, a bigger share of domestic public debt leads to wider income inequality. We also suggest steps that may halt the negative impact of public debt on equality in Lebanon, such as reforming the tax system, restructuring the public debt, and searching for sources other than borrowing to cover the budget deficit.
\end{abstract}

Keywords: Income inequality, Public debt, Domestic public debt, Economic growth, ARDL

JEL Codes: C22; D33; G01; G38; H6; O15

\section{Introduction}

Since the 1970s, income inequality has increased in almost all countries (Milanovic, 2016b). The top $10 \%$ income share has risen everywhere, while the top $1 \%$ have increased their share twice as much as the bottom 50\%; this rise is attributed to the policies adopted ever since that time (Alvaredo et al., 2017). On the other hand, since 1980, the increase in public debt has been the main reason that the net public wealth ${ }^{1}$ has declined in all countries ${ }^{2}$, which limited the governments' ability to support redistribution and reduce inequality. Therefore, not treating these issues can lead to political, economic, and social disasters (Alvaredo et al.,

\footnotetext{
${ }^{1}$ Net public wealth= Public assets - Public debt.

2 The net private wealth has risen from $200-350 \%$ of national income in 1970, to 400-700\% in 2016.
} 
2018a).

Previous literature has focused on the effect of growth on inequality. This paper examines the impact of public debt on inequality, while the empirical literature on this topic remains scarce. The theoretical framework of You and Dutt's (1996) hypothesis relates inequality and public debt and can be summarized as follows: the tax revenues from the working class are utilized to pay interests on the public debt, which is owned by a small minority of wealthy individuals. Based on that, government debt contributes to income inequality. Moreover, based on Salti's (2015) hypothesis, which proposes that domestic public debt which is largely held by domestic banks, has a regressive effect on income inequality; our hypothesis in this empirical study is that the Lebanese domestic public debt, which is largely held by domestic Lebanese banks has a significant positive (regressive) effect on the rise of income inequality; therefore, this effect may lead to social dissatisfaction.

Public debt is often divided into external and domestic debt. In this paper, we will be focusing on domestic public debt. Indeed, since domestic debt is largely held by domestic creditors (Panizza, 2008), examining the relationship between domestic public debt and income inequality helps to monitor local redistribution. Moreover, previous studies have shown that domestic debt has far greater regressive effects on income inequality than external public debt (Salti, 2015). Finally, according to Gopinath (2007), Arnone and Presbitero (2006), and Hauner (2009), domestic public debt in middle-income countries is mostly owned by domestic banks. Such characteristics are dominant in Lebanon, where the volume of domestic public debt is substantial and concentrated in the hands of a minority, particularly the banking sector (see Figure 1). We believe this might be causing an increased level of inequality, which, in turn, fosters societal instability.

In 2017, Lebanon ranked $3^{\text {rd }}$ after Japan and Greece among the countries with the highest debt-to-GDP ratio (149\%) (The World Factbook, the CIA). While public debt is often not a major economic issue, as many countries manage to coexist with high public debt for a long time (see Piketty 2014, Chapter 16), in Lebanon, economic and political factors are interrelated. Public policies are based on sectarianism and nepotism (World Bank, 2016). Furthermore, income and wealth are highly concentrated (Assouad, 2017). Therefore, a considerable share (40\% in 2018) of the overall governmental expenditure on public debt service - precisely domestic public debt - could have severe consequences on the country's social stability ${ }^{3}$.

\footnotetext{
3 At the end of 2019, wherein October 17, 2019, the popular dissatisfaction reached unprecedented limits which led to the breakout of the largest protests in the country. Moreover, during October and November, banks closed for many consecutive days and set up a limit for withdrawals.
} 


\section{MInstitute Macrothink}

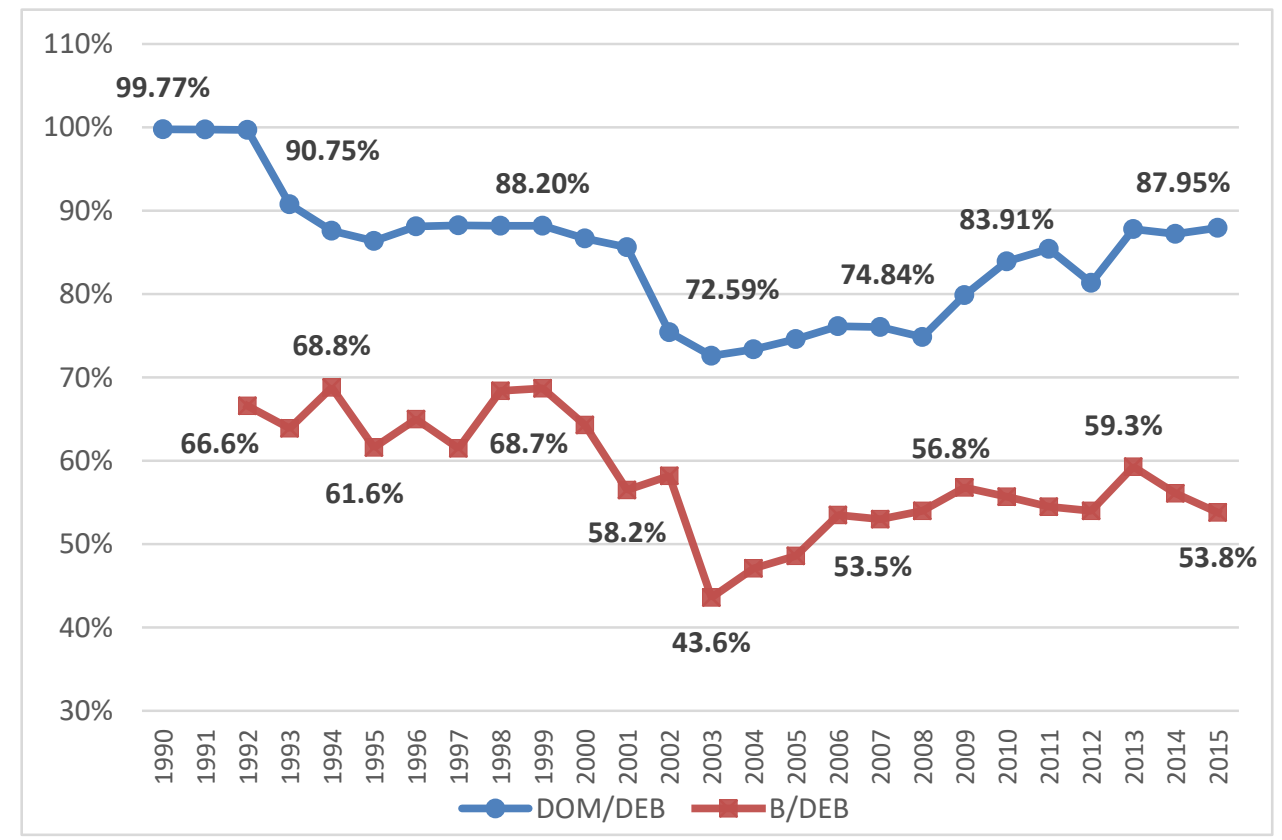

Figure 1. The Percentage of public debt held by Lebanese commercial banks (B/DEB), and the domestic share of public debt as \% of total debt (DOM/DEB)

This paper examines the impact of domestic public debt on income inequality in Lebanon. The data used covers the period between 1990 and 2015. The analysis is carried using Autoregressive Distributed Lag (ARDL) Model and the Error Correction Model (ECM) to check the existence of the short-run and long-run impact and the relationship between income inequality and domestic public debt, and other control variables. However, in this study, we examine the effect of domestic public debt on inequality, while the empirical literature on this topic remains scarce (Salti, 2015). To our knowledge, this paper is the first to study the impact of domestic public debt on income inequality in Lebanon. Moreover, it coincides with the biggest socio-economic crisis since the end of the country's civil war.

Our results show that the domestic share of public debt has a positive and significant effect on income inequality. These results hold in both the short and long run. They also hold using different control variables. Hence, a bigger share of domestic public debt leads to wider income inequality. Likewise, economic growth in Lebanon has a positive and significant effect on income inequality.

The paper is organized as follows: Section 1 introduces the paper's motivation and discusses the conditions of public debt and income inequality in Lebanon. Section 2 presents the existing literature; section 3 introduces data and empirical models. Section 4 discusses the results, and section 5 concludes the paper with policy recommendations.

\subsection{Public debt in Lebanon: Fast Accumulation and Record Numbers}

Upon the end of the Lebanese Civil War (1975-1990), a massive reconstruction process was initiated in Lebanon, which was funded by loans. In few years, the debt-to-GDP ratio 


\section{I Macrothink}

Business and Economic Research

ISSN 2162-4860

2020, Vol. 10, No. 4

increased from $50 \%$ (1992) to $102 \%$ (1997), and in 2018, it was estimated at 152\% (Ministry of Finance, 2018) (figure 2). This increase is due to many reasons. First, the government relied on borrowing as the main resource to cover its fiscal deficit. The deficit was caused by the cost of reconstruction and the increase in public debt service.

Furthermore, despite the strong positive correlation between public debt and wars (Azzimonti et al., 2012), the cost of reconstruction became marginally small compared to the public debt service cost. Consequently, the debt service became the main cause of the budget deficit. In this context, a report released in 2007 by the Lebanese Ministry of Finance (MOF) shows that after the increase of debt service to a record figure in 2001 (48\% of the overall governmental expenditure), the government decided to accumulate new debt through the donors' conference "Paris 2", where it received 2.4 billion U.S. dollars in the form of long-term soft loans. These loans made the public debt service decline to $33 \%$ of the overall government expenditure in 2005. However, according to the same report, the effects of "Paris 2" were over in 2006. The debt service increased again by $30 \%$ (compared to 2005). Therefore, to decrease the level of debt service and to set the expenditure on debt service to decrease, the government aimed at holding the "Paris 3" conference (MOF, 2007). The second reason is correlated with the first. The rate of return on treasury bonds is an increasing function of the degree of indebtedness of the public sector (Hendrik, 1985). However, the interest rate on treasury bonds in Lebanon was extremely high in the 90s, reaching 37\% in 1995 (figure 3). This accelerated the accumulation of debt.

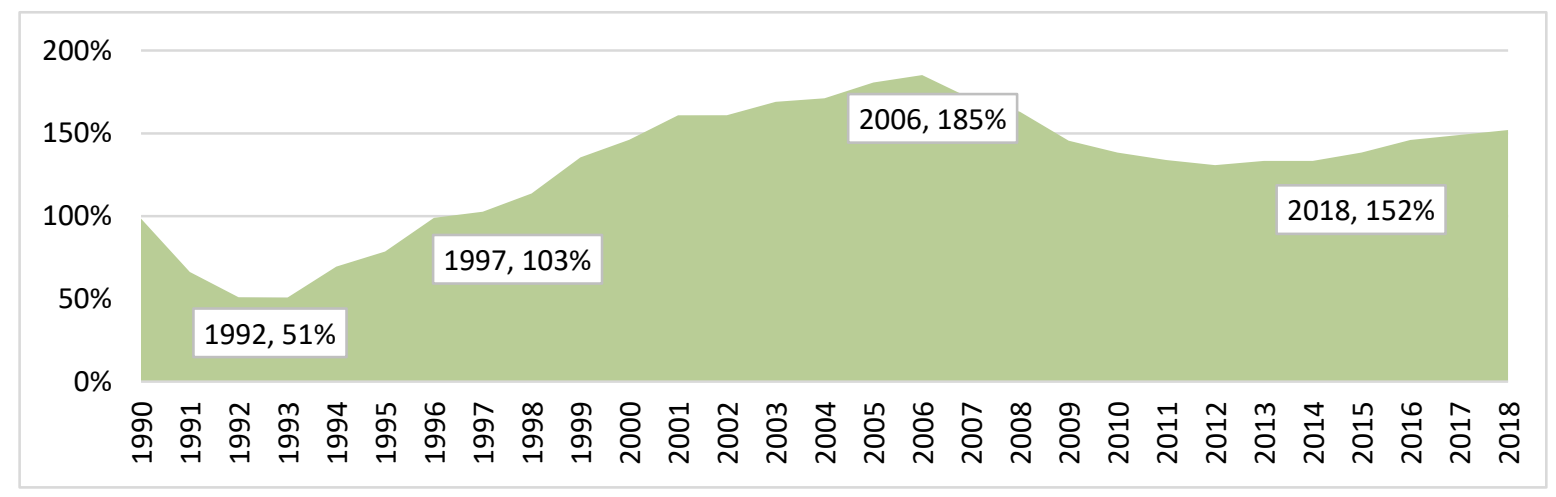

Figure 2. Public debt to GDP ratio, 1990-2018 


\section{MInstitute Macrothink}

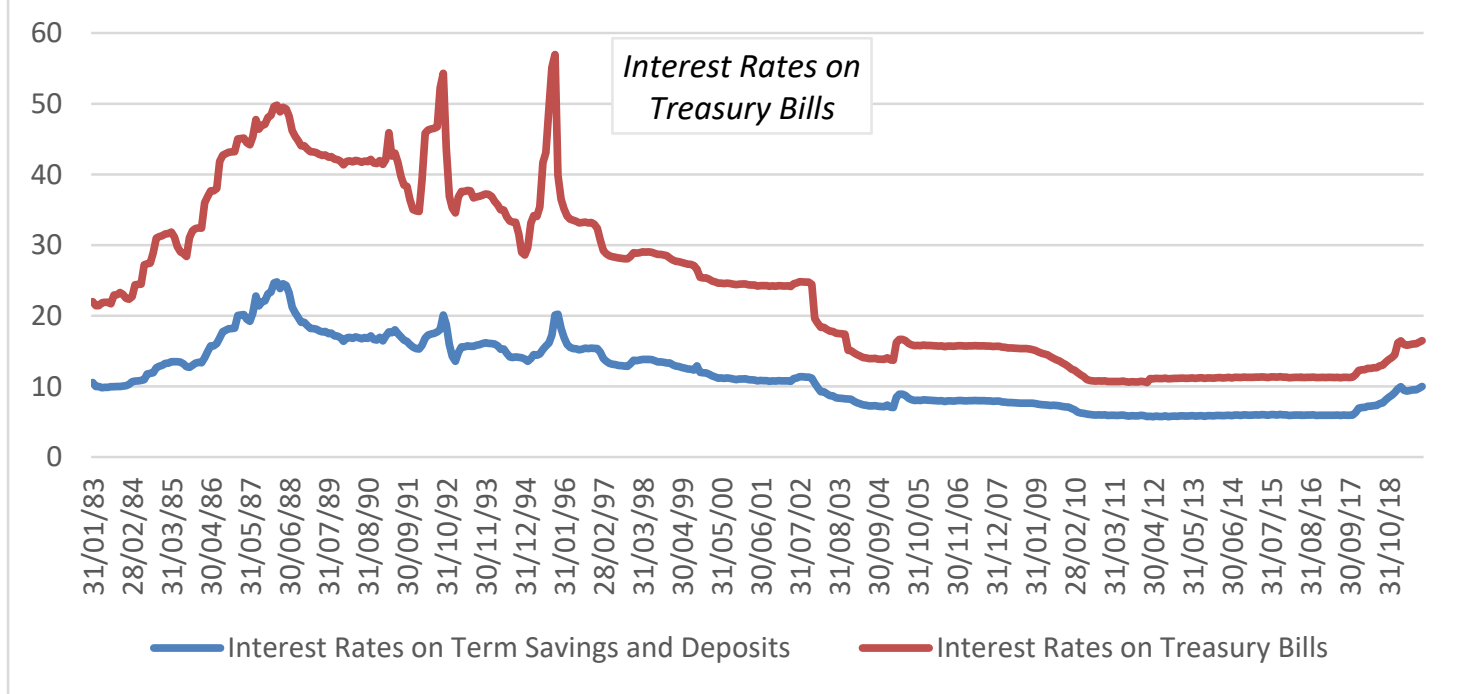

Figure 3. Interest rates on treasury bills and on term savings and deposits, 1983-2018

\subsection{Who Benefits from The Public Debt in Lebanon?}

In some cases, public debt benefits wealth holders and their inheritors (Piketty, 2014). Does this apply to Lebanon? Many factors contributed to attracting owners of capital and wealth to invest in Lebanese public debt. As indicated before, on the one hand, such investments were encouraged by demands for governmental borrowing during the period between 1993 and 2018. They were also motivated by the huge gap (1988-2000) between interest rates on treasury bonds, and interest rates on term savings and deposits, as shown by figure 3 . This figure also shows that the difference between the two rates reached 20 points in 1995 . This allowed treasury bonds holders to accumulate easy, quick, and guaranteed earnings. Investing in public debt became thus a very attractive deal for capital and wealth owners. That is what the banking sector has done in Lebanon. Figure 1 shows that this sector held two-thirds of the public debt in the 90s, and that is highly invested in treasury bonds (68.8\% in 1994 and $68.7 \%$ in 1999). What were then the results of this investment? The net profit of Lebanese banks reached $\$ 22.6$ billion in 26 years (1993-2018) (ABL, 2018). Furthermore, the profits of the top 10 banks increased by $280 \%$ in 10 years (from $\$ 1,004 \mathrm{M}$ in 2008 to $\$ 2,805 \mathrm{M}$ in 2017) when twenty years earlier, profits of the banking sector in Lebanon did not exceed $\$ 436 \mathrm{M}$ (Dibeh, 2005). This refers back to Piketty (2014), who considered that Marx was right when he considered that public debt is nothing but a tool that serves the accumulation of private capital.

\subsection{The Reality of Inequality in Lebanon}

Until 2015, most of the literature regarding the Middle East (including Lebanon) considered the level of income inequality in this region to be low according to world standards (Hassine, 2015; World Bank, 2014; El-Laithy et al., 2008). However, recent studies confirmed that this region had become the most unequal in the world (Alvaredo et al., 2017; Alvaredo \& Piketty, 2014; Alvaredo et al., 2018b). While income inequality has been increasing since the 1970s 


\section{$\triangle 1$ Macrothink}

Business and Economic Research ISSN 2162-4860 2020, Vol. 10, No. 4

in most countries (Alvaredo et al., 2018a; Milanovic, 2016a; Piketty \& Zucman, 2014; Ortiz \& Cummins, 2011), Lebanon ranks among countries with the highest levels of inequalities. As for wealth distribution, the International Wealth Report 2018 (Shorroks et al., 2018) indicates that Lebanon ranks $5^{\text {th }}$ internationally in wealth inequality. Only $0.3 \%$ of the population owns more than one million dollars, whereas $77.4 \%$ own less than $\$ 10,000$. Moreover, the report published by the IMF (2017) shows that bank deposits are highly concentrated: less than $1 \%$ of the total number of bank accounts own $50 \%$ of all deposits, and less than $0.1 \%$ of accounts own $20 \%$ of total deposits.

As for income inequality, and based on the World Bank calculations of Gini coefficients, Lebanon ranked $3^{\text {rd }}$ internationally in 2014 (Saliba et al., 2017) (See Figure A1). Assouad (2017) studied income and wealth inequality in Lebanon between 2005 and 2014. She concluded that there is a high concentration of income and wealth in Lebanon. The top 1\% of the population receives $25 \%$ of total income and $40 \%$ of the wealth. The top $10 \%$ hold $55 \%$ of income and $70 \%$ of the wealth. And while the top $0.1 \%$ gets $11 \%$ of income, the bottom $50 \%$ get $11 \%$ of the total income (see Figures 4 and A2). To stress the huge discrepancies, Assouad (2017) explained that only a small fraction of the Lebanese population benefits from this economic model, which is based on tourism, the banking sector, real estate, and the inflow of remittances.

Those results coincided with the findings of another study done by Saliba et al. (2017) on the distribution of income for workers in the private sector in Lebanon. It revealed that Lebanon suffers from high levels of inequality and that the level of income to the top $2 \%$ income group is close to the level of income to that of the bottom $60 \%$ (17\% and $22 \%$, respectively). Moreover, Lebanon's Gini coefficient is as high as 50.7. Thus, in 2017, and based on income equality, Lebanon ranks $129^{\text {th }}$ out of 141 countries.

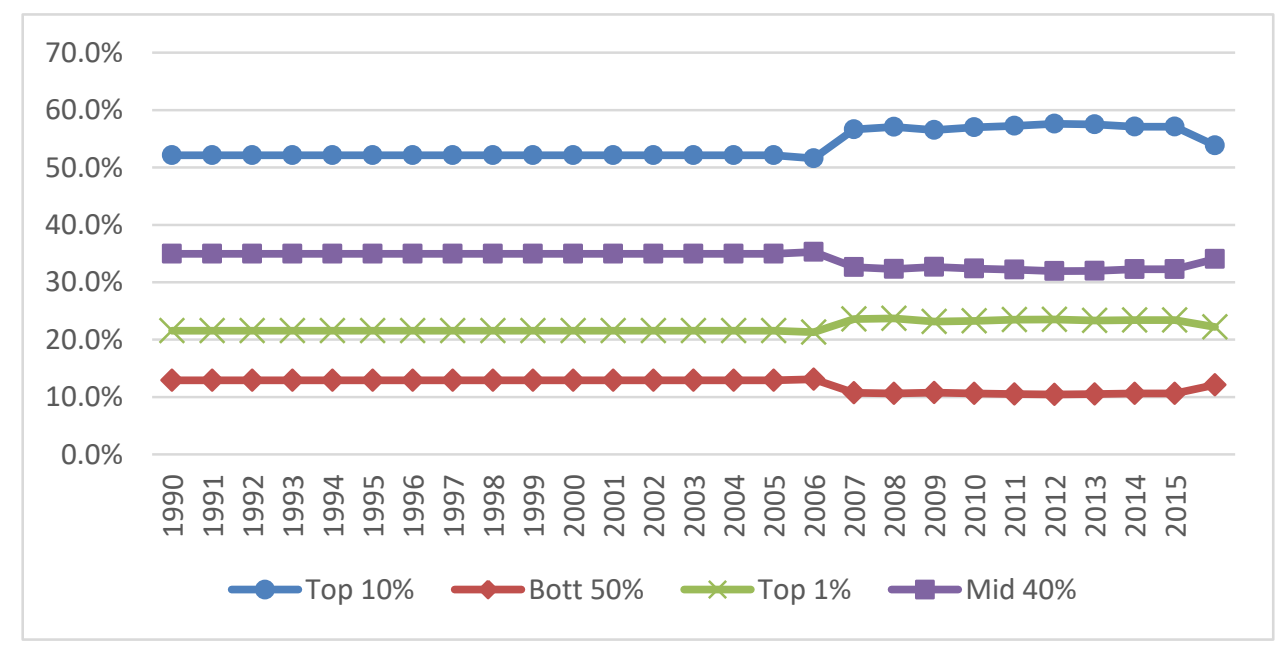

Figure 4. Income shares in Lebanon, 1990-2015

\subsection{Relationship between Public Debt and Income Inequality in Lebanon}

In Lebanon, public debt could become an issue due to its contribution to inequality. The 
accumulation of public debt, especially domestic public debt in the hands of a minority of citizens, the high ratio of public debt to GDP, leading to high debt service, is the real problem. Debt service is almost equal to all basic government expenditures (See Figures 5 and A.3). Throughout 1997-2006, government expenditure on debt service was, on average, $40 \%$ of all expenditures (reaching 50\% in certain years). Since 1993, it was always higher than expenditure on wages and salaries for all public sector employees combined. Thus, the government's ability to support redistribution of projects, which may limit and decreases inequality levels such as spending on education, health, and skills became low (see Salti, 2015; Milanovic, 2016a; Wilkinson \& Pickett, 2006; Abdullah et al., 2013; Gregorio \& Lee, 2002).

Besides, the taxation system plays the main role in the process of redistribution. While Piketty suggests imposing exceptional progressive taxes on income and wealth for a certain period to reduce public debt and consequently to put an end to the negative impact of debt on inequality, The Lebanese taxation system is mainly based on indirect taxes levied on goods and services (import duties, value-added tax (VAT), and the tax on telecoms) rather than on personal incomes and wealth. Basic taxes treat everyone equally, whether poor or rich, making the Lebanon taxation system a regressive system (Salti \& Chaaban, 2010). This includes the few who benefit from the economic model to accumulate their wealth (Assouad, 2017). In this model, the taxation system contradicts justice and equality.

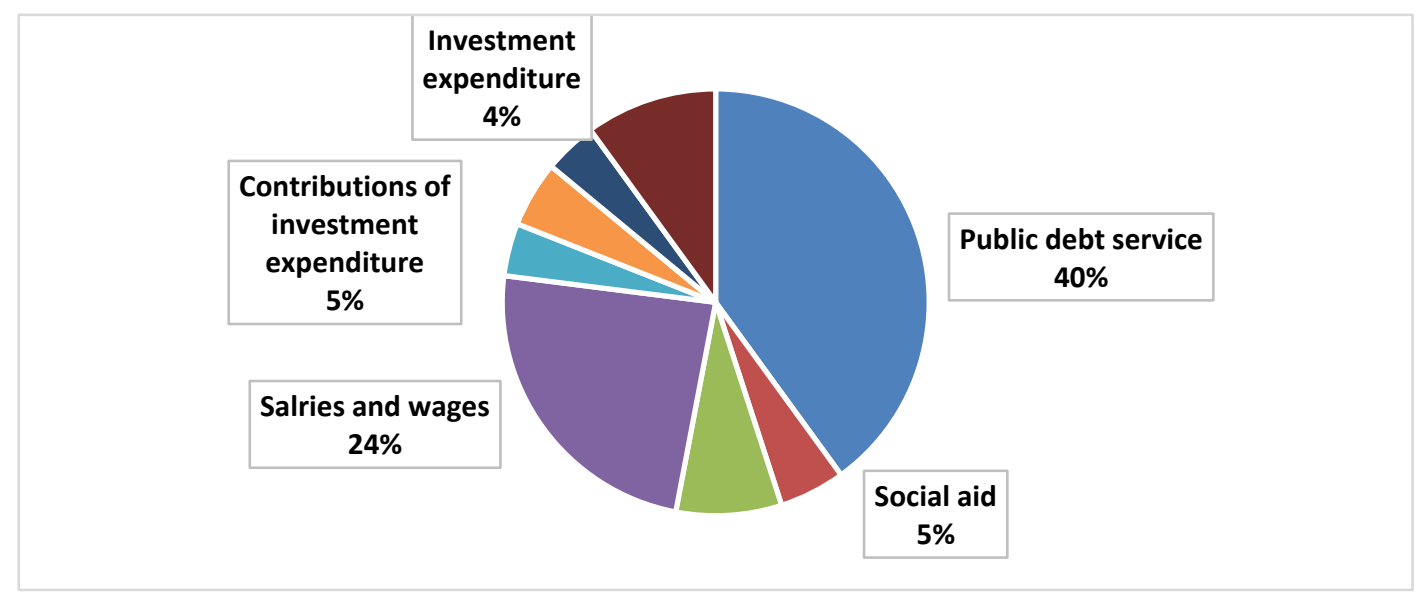

Figure 5. Total budgetary and Treasury expenditure 1997 - 2006

\section{Review of literature}

There is no consensus on the impact of public debt on income inequality. Some researchers believe that there is no correlation between the paths of inequality and debt. Inequality could have a fluctuating trend of ups and downs (Atkinson et al., 2011; Milanovic, 2016b) when public debt increases (Jabłoński et al., 2015).

Classical economists of the $18^{\text {th }}$ and $19^{\text {th }}$ centuries believed that public debt has a destructive effect on the economics of nations (Smith, 1776, p. 878; Ricardo, 1817, p. 247). Say (1821, p. 412) conclude that "the lender loses no part of revenue; the only loser is the payer of taxes". 
Baumstark (1833, p. 385) mentioned that in the course of accumulating public debt, “[...] wealth passes from the hands of the middle and lower class more and more into the hands of the richest, and in the same, if not greater proportion poverty in those two increases, in which the wealth accumulates for the richest".

You and Dutt (1996) considered that state revenues generated from taxes collected from the working class are paid as high interests on government debt, which is owned exclusively by a small fraction of rich individuals. This leads to the contribution of public debt to income inequality. As state deficit increases, the need for more loans intensifies. The growing debt requires the state to impose new taxes on the poor to pay off the new loans. This income redistribution process from the poor to the rich widens the gap between the two and increases inequality.

Piketty believed that when a few citizens own a large share of public debt, the internal redistribution of income is bound to happen in a country. Moreover, according to him, "ultimately, government debt is nothing more than a claim of one portion of the population (those who receive interest) on another (those who pay taxes)" (Piketty, 2014, p. 144).

Azzimonti et al. (2012) believed that public debt grows faster when the economy slows down. This increases the share of the top $1 \%$ of the total income. Larch (2012) indicates that financial performance is affected by various degrees of income inequality. It shows that countries suffering from high inequality levels also suffer from a big deficit in their budget. They also tend to accumulate large government debts. Using panel data on 120 countries for the period 1990 - 2007, Salti (2015) examined the effect of the composition of public debt on income inequality. She found that domestic public debt has a regressive impact on income inequality. This result still significant and correct across all specifications, even controlling for a set of control variables, mainly as various government spending variables, political conflict, debt servicing, corruption, and total debt.

Other theoretical and empirical studies focus on the relationship between the distribution of income and other factors. Michl (1991) found that in the USA, the national debt's interest has a regressive effect on the redistribution of income. Forslund et al. (2016) indicated that in developing countries, domestic debt and inflation have a negative correlation. Li et al. (2000) examined the effects of corruption on income and growth; they found that the relationship between income and corruption has an Inverted-U shape.

Kuznets (1955) studied the relationship between income inequality and growth; he concluded that this relation would take an Inverted-U shape (Kuznets curve); he believed that inequality rates in the early stages of growth would rise, reaching their peak; then they would gradually decrease. Many theoretical and empirical studies support the Kuznets theory (Ram, 1991; Dawson, 1997; Riggs et al., 2012; Desbordes \& Verardi, 2012; Zhan, 2016). Piketty and Saez (2003) concluded that Kuznets was wrong; inequality in the USA has been rising since the 1970s and that the curve takes the form of "U" not "U-invert".

\section{Data and Variables}

This study uses annual time series data from 1990 to 2015. Our model includes three main 
variables and a set of control variables, which the literature showed to have a strong relationship with our topic (Prechel, 1985; Jabłoński et al., 2015; Azzimonti et al., 2012; Salti, 2015; Barro, 2000; Forslund et al., 2016). The main variables are income inequality measured by the Top 10\% income share (Top 10\%); The domestic share of public debt (DOM/DEB); and Economic growth measured by the GDP per capita (GDPPC).

Top $10 \%$ is collected from "World Inequality Data - WID". We choose this variable to measure inequality for many reasons. First, some works cited in this paper use this indicator (Kwon, 2016; Sanyal \& Elhen, 2017; Sayed \& Peng, 2020). Second, one of the advantages for this indicator is that it has been available for a long period: indeed, in the Lebanese case, the GINI index which is used by most of the research, has been available sporadically, while the top $10 \%$ is fully available for all the period between $1990-2015$.

GDP per capita is collected from two sources, the World Bank's World Development Indicator (WDI) and Maddison Project 2018 version. The public debt and its composition are collected from a variety of sources, including the Lebanese Central Bank (CBL), the Lebanese Ministry of Finance (MOF), the International Monetary Fund (IMF), the Historical Public Debt Database (HPDD), and the IMF World Economic Outlook Database (WEO).

For Lebanon, available data does not include a clear indicator that measures the domestic public debt. However, based on Vasishtha (2007) and Salti (2015), the public debt in a current currency can be used to measure the domestic public debt, so this paper defines the domestic public debt as all the public debt in Lebanese currency plus the foreign-currency public debt held by the Lebanese commercial banks. Data for the composition of domestic public debt is collected from the CBL and a set of reports published by the Lebanese MOF.

Domestic Public Debt = public debt in Lebanese currency held by Central Bank, Non-Bank, and Lebanese Banks + public debt in foreign currency held by Lebanese banks.

In addition to these variables, our study uses a combination of control variables, namely, inflation (INF) collected from WEO, government expenditure (GOV_EX) come from MOF, control of corruption (COC) collected from The Worldwide Governance Indicators (WGI), total public debt in billions of \$ (TDEB) and total debt as \% of GDP (DEB/GDP) collected from (CBL, MOF, WDI, IMF).

In this paper, we also use a set of interaction terms to test some hypothesis, which can clearly explain the mechanisms of the relation between public debt and inequality (Salti, 2015). Those interaction terms are as follows: the interaction between the domestic share of public debt (DOM/DEB) and government expenditure (GOV_EX) and its label as (DOM_GOV). The second one is between DOM/DEB and GDP, its label as (DOM_GDP).

Table 1 presents descriptive statistics for the variables used in this paper. All these data are showing in figures 1, 2, 3, 4, A1, and A2. Data in figure 1 are collected from CBL, and data in figures 5 and A3 are collected from the Ministry of Finance (MOF, 2007). 
Table 1. Descriptive Statistics

\begin{tabular}{|l|l|l|l|l|l|}
\hline Variable & Obs & Mean & Std. Dev. & Min & Max \\
\hline TOP 10\% & 26 & 0.5382973 & 0.0242832 & 0.5158994 & 0.5760379 \\
\hline BOT 50\% & 26 & 0.1213038 & 0.0112463 & 0.1044 & 0.1311 \\
\hline TOP 1\% & 26 & 0.2220115 & 0.0091234 & 0.2131 & 0.2369 \\
\hline DOM/DEB & 26 & 84.82039 & 7.873667 & 72.59259 & 99.76843 \\
\hline DEB/GDP & 26 & 127.9792 & 39.98859 & 50.79 & 185.19 \\
\hline TDEB & 26 & 32.10634 & 21.46707 & 2.796476 & 70.32 \\
\hline TDOM & 26 & 26.42093 & 18.00773 & 2.79 & 61.84543 \\
\hline DOM_DEB & 26 & 19.42837 & 11.98264 & 2.79 & 43.2471 \\
\hline B/TDEB & 24 & 58.0625 & 6.908899 & 43.6 & 68.8 \\
\hline GDPPC & 26 & 11838.27 & 2537.882 & 6224 & 16315 \\
\hline GDP & 26 & 23.19165 & 14.11261 & 2.838485 & 49.97389 \\
\hline GOV_EX & 26 & 7.251791 & 4.07994 & 0.95 & 13.95158 \\
\hline INF & 26 & 8.111115 & 3.755415 & 3.307 & 18.095 \\
\hline COC & 20 & -0.7257058 & 0.1897444 & -1.037225 & -0.4454119 \\
\hline
\end{tabular}

\section{Empirical Model}

Our hypothesis for this empirical study is that the Lebanese domestic public debt, which is largely held by domestic Lebanese banks, has a positive significant (regressive) effect on the rise of income inequality, then, the more the domestic share of public debt is, the high the inequality in income is. Therefore, this effect leads to social dissatisfaction.

To test this hypothesis, we used the Autoregressive Distributed Lag (ARDL) model proposed by Pesaran et al. (2001) and Error Correction Model (ECM). The ARDL model has many advantages in comparison with other cointegration methods (see, Nkoro \& Uko, 2016; Bal \& Rath, 2014; Kripfganz \& Schneider, 2016), and for this study, we employ this approach for three reasons. First, the ARDL model is more suitable and efficient in the case of a small and limited sample data period (our period is relatively small $\mathrm{T}=26$ years). Secondly, with this approach no need for our variable to be integrated of the same order; the ARDL technique can be applied whether variables are I (0), I (1), or mixed but not I(2). Third, using the ARDL method, the long-run estimates of the model are obtained (Pesaran et al., 2001), and the ECM can be derived from the ARDL model through a simple linear transformation, which integrates short-run adjustments with long-run equilibrium without losing long run information.

To utilize these advantages, this empirical analysis will follow these steps. First, we will use the ADF unit root test to check the stationarity of our data and to determine the order of the series. Suppose no variable is integrated of second-order I(2). In that case, the second step will be the bounds F-statistics test, which is used to identify the existence of a long-run relationship among the variables. If calculated F-statistics is higher than the upper limit critical values, this means our variables are co-integrated. We will then estimate both the 
short-run dynamics and long-run relationships using a log-level ARDL error correction method. Therefore, the next step is to estimate the long-run relationship between the variables from the following equation:

$$
\Delta Y_{t}=\beta_{0}+\sum_{i=1}^{p} \gamma_{i}^{j} \Delta Y_{t-i}+\sum_{i=1}^{q} \gamma_{i}^{j} \Delta X_{t-i}+\beta_{i} \sum_{i=1}^{p} Y_{t-1}+\beta_{i} \sum_{i=0}^{q} X_{t-1}+\varepsilon_{t}
$$

where $Y_{t}$ is a set of dependent variables include Top 10\%, GDPPC, and DOM/DEB; and $X_{t}$ is a vector of control variables include INF, GOV_EX, TDEB, COC, DOM_GOV, and DOM_GDP; $\beta_{0}$ is an intercept. $\Delta$ is the first difference. The $\beta_{i}($ for $i=1,2, \ldots$,$) represent the long-run$ relationship between the dependent and independent variables in our model. And $\gamma_{i}^{j}$ (for all j) represent the short-run relationship. $\varepsilon_{t}$ is the error term. $q$ and $p$ are optimal lag orders.

As an example, when Top $10 \%$ is the dependent variable, and the independent variables are $\log$ DOM/DEB, log GDPPC, and a set of control variables include INF, TDEB, and GOV_EX. Eq.1 can be written as follows:

$$
\begin{gathered}
\Delta T O P 10_{t}=\beta_{0}+\beta_{1} \sum_{i=1}^{p} T O P 10_{t-1}+\beta_{2} \sum_{i=0}^{q_{1}} l D O M / D E B_{t-1}+\beta_{3} \sum_{i=0}^{q_{2}} l g d p p c_{t-1}+ \\
\beta_{4} \sum_{i=0}^{q_{3}} T D E B_{t-1}+\beta_{5} \sum_{i=0}^{q_{4}} G O V_{-} E X_{t-1}+\beta_{6} \sum_{i=0}^{q_{5}} I N F_{t-1}+\sum_{i=1}^{p} \gamma_{i}^{I} \Delta T O P 10_{t-i}+ \\
\sum_{i=1}^{q} \gamma_{i}^{D} \Delta I D O M / D E B_{t-i}+\sum_{i=1}^{q} \gamma_{i}^{G} \Delta l g d p p c_{t-i}+\sum_{i=1}^{q} \gamma_{i}^{T} \Delta T D E B_{t-i}+ \\
\sum_{i=1}^{q} \gamma_{i}^{G O} \Delta G O V_{-} E X_{t-i}+\sum_{i=1}^{q} \gamma_{i}^{I F} \Delta I N F_{t-i}+\varepsilon_{t}
\end{gathered}
$$

After estimating the long-run relationship, the next is to obtain the short-run dynamic parameter and to know the speed of adjustments or the error correction mechanism (ECM). The specification of the model with ECM is as follows:

$$
\Delta Y_{t}=\beta_{0}+\sum_{i=1}^{p} \gamma_{i}^{j} \Delta Y_{t-1}+\sum_{i=1}^{q} \gamma_{i}^{j} \Delta X_{t-1}+\delta E C M_{t-1}+\varepsilon_{t}
$$

where, $\delta E C M_{t-1}$ is the error correction term, and $\delta$ is the speed of adjustment, which is expected to have a negative sign. Just like Eq.1, and with the same dependent and independent variables, Eq. 2 can be written as follows:

$$
\begin{gathered}
\triangle T O P 10_{t}=\beta_{0}+\sum_{i=1}^{p} \gamma_{i}^{I} \Delta T O P 10_{t-i}+\sum_{i=1}^{q} \gamma_{i}^{D} \Delta l D O M / D E B_{t-i}+\sum_{i=1}^{q} \gamma_{i}^{G} \Delta l g d p p c_{t-i}+ \\
\sum_{i=0}^{q} \gamma_{i}^{T} \Delta T D E B_{t-i}+\sum_{i=0}^{q} \gamma_{i}^{G O} \Delta G O V_{-} E X_{t-i}+\sum_{i=0}^{q} \gamma_{i}^{I F} \Delta I N F_{t-i}+\delta E C M_{t-1}+\varepsilon_{t}
\end{gathered}
$$

Then, using the above equations, the log-level ARDL error correction approach is written as follow:

$$
\Delta Y_{t}=\beta_{0}+\sum_{i=1}^{p} \gamma_{i}^{j} \Delta Y_{t-1}+\sum_{i=1}^{q} \gamma_{i}^{j} \Delta X_{t-1}+\beta_{i} \sum_{i=1}^{p} Y_{t-1}+\beta_{i} \sum_{i=0}^{q} X_{t-1}+\delta E C M_{t-1}+\varepsilon_{t}
$$




\section{Macrothink}

Using the same variable in equations 2 and 4, Eq.5 can be written as follows:

$$
\begin{gathered}
\Delta T O P 10_{t}=\beta_{0}+\beta_{1} \sum_{i=1}^{p} T O P 10_{t-i}+\beta_{2} \sum_{i=0}^{q_{1}} \operatorname{lDOM} / D E B_{t-i}+\beta_{3} \sum_{i=0}^{q_{2}} \operatorname{lgdppc}_{t-i}+ \\
\beta_{4} \sum_{i=0}^{q_{3}} T D E B_{t-i}+\beta_{5} \sum_{i=0}^{q_{4}} G O V_{-} E X_{t-i}+\beta_{6} \sum_{i=0}^{q_{5}} I N F_{t-i}+\sum_{i=1}^{p} \gamma_{i}^{I} \Delta T O P 10_{t-i}+ \\
\sum_{i=1}^{q} \gamma_{i}^{D} \Delta l D O M / D E B_{t-i}+\sum_{i=1}^{q} \gamma_{i}^{G} \Delta l g d p p c_{t-i}+\sum_{i=0}^{q} \gamma_{i}^{T} \Delta T D E B_{t-i}+ \\
\sum_{i=0}^{q} \gamma_{i}^{G O} \Delta G O V_{-} E X_{t-i}+\sum_{i=0}^{q} \gamma_{i}^{I F} \Delta I N F_{t-i}+\delta E C M_{t-1}+\varepsilon_{t}
\end{gathered}
$$

\section{Empirical Results}

This empirical study aims to investigate long-run and short-run relationships between income inequality and public debt in Lebanon using ARDL and ECM model estimation techniques.

\subsection{Unit Root Test}

Testing for stationarity in time series data is important to decide on the estimation method. Therefore, based on Pesaran et al. (2001), if the variables are integrated of different orders (I(0) and I(1), but not $\mathrm{I}(2)$ ) or have a combination of $\mathrm{I}(0)$ and $\mathrm{I}(1)$, the autoregressive distributed lags model (ARDL) cointegration technique can be used. So, the first step is testing for stationarity; the Augmented Dickey-Fuller (ADF) unit root test proposed by Dickey and Fuller (1979) was employed. The null hypothesis for this test is that variables are no stationary. The results are presented in Table 2, and they clearly show that our study sample is a mix of $I(0)$ and $I(1)$, and none of our variables is $I(2)$, which prompts us to use the ARDL cointegration technique which is the suitable model to estimate a consistent and effective estimation in mixed integration test results cases.

Table 2. Results of the unit root test

\begin{tabular}{|l|l|l|l|}
\hline Variables & Level & $\boldsymbol{I}^{\text {st }}$ diff & Inference on integration \\
\hline TOP 10\% & -0.722 & $-5.029^{*}$ & $I(1)$ \\
\hline IGDPPC & $-3.985^{*}$ & - & $I(0)$ \\
\hline sqIGDPPC & $-3.816^{*}$ & - & $I(0)$ \\
\hline TDEB & 2.157 & $-2.928^{* *}$ & $I(1)$ \\
\hline TDEB_GDP & -0.915 & $-3.524^{*}$ & $I(1)$ \\
\hline TDOM_P_TDEB & -2.004 & $-3.980^{*}$ & $I(1)$ \\
\hline B_TDEB & -0.150 & $-4.231^{*}$ & $I(1)$ \\
\hline TDEB_SER_P_GNI & -0.798 & $-6.111^{*}$ & $I(1)$ \\
\hline INT_TDOM & -1.845 & $-6.460^{*}$ & $I(1)$ \\
\hline INF & -2.057 & $-4.949^{*}$ & $I(1)$ \\
\hline COC & -1.363 & $-5.514 *$ & $I(1)$ \\
\hline GOV_EX & -0.462 & $-3.764 *$ & $I(1)$ \\
\hline
\end{tabular}

Note. ${ }^{*}$ Denote statistically significant at $1 \%$ level, ${ }^{* *}$ at $5 \%$, and ${ }^{* * *}$ at $10 \%$. 


\subsection{Cointegration Test}

After we confirmed that the variables are integrated into different orders, the second step is to test for cointegration using the ARDL bounds test approach (based on the ECM) developed by Pesaran et al. (2001). This test identifies the existence of a long-run relationship between the dependent and independent variables. The bounds test is mainly based on the joint $F$-statistic, the null hypotheses $\left(H_{0}\right.$ : no cointegration) and the alternative hypothesis $\left(H_{1}:\right.$ a co-integrating relationship) of this test are as follows:

$$
H_{0}: \beta_{1}=\beta_{2}=\beta_{3}=\beta_{4}=0 \text { and } H_{1}: \beta_{1} \neq \beta_{2} \neq \beta_{3} \neq \beta_{4} \neq 0
$$

If the calculated F-statistic is lower than the critical values of the lower bound (Pesaran et al. 2001), we accept null hypotheses, which means that there is no long-run relationship between the variables; oppose to the alternative means that there is a long-run relationship among the variables. The results are shown in Table 3.

The results presented in Table 3 show that in all models, the calculated F-statistic is higher than the critical values, with a difference on the level of significant $(1 \%, 2.5 \%, 5 \%$, or $10 \%)$. Thus, we reject the null hypothesis of no cointegration between our variables, which implies there is a long-run relationship between income inequality, GDP per capita, Public debt, and the other control variables.

Table 3. Bounds testing results

\begin{tabular}{|c|c|c|c|c|}
\hline \multirow{2}{*}{ Cointegration hypotheses } & \multirow{2}{*}{ F-statistics } & \multicolumn{2}{|c|}{ Bound critical values* } & \multirow{2}{*}{ Decisior } \\
\hline & & $I(0)$ & $I(1)$ & \\
\hline $\begin{array}{l}F(T O P 10 \mid \text { IDOM } \\
/ D E B \text { lGDPPC TDEB GOV_EX INF) }\end{array}$ & $3.874^{\mathrm{c}}$ & 2.62 & 3.79 & CE exis \\
\hline $\begin{array}{l}F(T O P 10 \mid \text { IDOM } \\
\text { /DEB lGDPPC DOM_GOV INF })\end{array}$ & $3.547^{\mathrm{d}}$ & 2.45 & 3.52 & CE exis \\
\hline $\begin{array}{l}F(T O P 10 \mid D O M \\
/ D E B \text { lGDPPC lDOM_GDPINF })\end{array}$ & $3.838^{\mathrm{d}}$ & 2.45 & 3.52 & CE exis \\
\hline$F(T O P 10 \mid l D O M / D E B$ LGDPPC COC INF) & $13.107^{\mathrm{a}}$ & 3.74 & 5.06 & CE exis \\
\hline
\end{tabular}

Notes. ${ }^{\text {a }}$ Significant at 0.01 level; ${ }^{b}$ at 0.025 level; ${ }^{\mathrm{c}}$ at $0.05 \mathrm{level} ;{ }^{\mathrm{d}}$ at 0.10 level. $*$ represents the Pesaran et al. (2001) critical values corresponding to an accepted level of significance. CE $=$ Cointegration Equation.

\subsection{Long-run and Short-run Estimation Results}

After we verified the presence of cointegration in our model, the next step is to estimate the long-run and short-run coefficients using ARDL and ECM estimation methods. Eq. (5) is used to present the ARDL error correction estimations (all equations are presented in appendix B). The estimates' results for both the long-run and short-run are shown in Tables 4.

Table 4 column 1 reports the results of the regression of Model I, where the dependent variable is Top $10 \%$, and the independent variables are log DOM/DEB, log GDPPC, and a set 
of control variables, which include INF, TDEB, and GOV_EX. The above results illustrate that in the long-run, both domestic public debt (DOM/DEB) and GDP per capita (GDPPC) in Lebanon have a positive and significant effect (at the $1 \%$ level) on income inequality. Therefore, an increase in the domestic share of public debt and economic growth in Lebanon gives rise to the level of income inequality. In the short run, domestic public debt has a positive effect, but it is not significant, and GDP per capita still has a positive and significant impact on income inequality.

For the control variables, in both the short and long run, total debt has a positive effect on income inequality; in other words, the more public debt, the more the inequality in the Lebanese economy. The coefficient of the public debt (0.0021) is less than the coefficient of domestic debt (0.132); this implies that domestic debt has more effect on income inequality than the total public debt (including domestic and external debt). Inflation and Government expenditure are not significant. In the short-run, with one lag, government expenditure has a positive and significant effect on income inequality.

As for the error correction term (ECM (-1)), which measures the speed of adjustment, a significant and negative term indicates how fast variables return to equilibrium. Our results show that the estimated coefficient of ECM (-1) is negative and highly significant (-0.909). Therefore, this result indicates that the speed of adjustment between the long-run and short-run dynamics is fast and indicates an adjustment mechanism of $90.9 \%$ towards the long-run equilibrium after a year.

Table 4 also reports the results of a series of diagnostic and stability tests; those tests are related to the goodness of fit of the ARDL error correction model. The first test is the Bruesch-Godfrey test; this test is used to check for serial correlation; the null hypothesis for this test is the absence of serial correlation. The results from table 4 indicate the absence of serial correlation. The second test is the white test; this test examines heteroscedasticity. The null hypothesis for this test is the absence of heteroscedasticity. Based on the results in Table 4, we accept the null hypothesis of homoscedasticity. The third test is the Autoregressive conditional heteroscedasticity (ARCH) LM test; the null hypothesis for this test is no ARCH. Also, from the results presented in Table 4, we accept the null hypothesis. 
Table 4. Estimated ARDL models, long-run and short-run coefficient

\begin{tabular}{|c|c|c|c|c|}
\hline \multirow[t]{2}{*}{ Independent variables } & \multicolumn{4}{|c|}{ Dependent variables: Top $10 \%$} \\
\hline & $\begin{array}{l}I \\
A R D L(1,1,0,0,2,0)\end{array}$ & $\begin{array}{l}\text { II } \\
A R D L(1,0,1,0,1)\end{array}$ & $\begin{array}{l}\text { III } \\
A R D L(1,0,2,0,0)\end{array}$ & $\begin{array}{l}\text { IV } \\
A R D L(1,0,0,1,1)\end{array}$ \\
\hline \multicolumn{5}{|l|}{ Long-run estimates } \\
\hline IDOM $/ D E B$ & $0.1317 * \quad(3.03)$ & $0.024 *(2.86)$ & $0.029 * * *(1.99)$ & $0.058 *(2.75)$ \\
\hline IGDPPC & $0.1031 *(3.37)$ & $0.072 *(2.66)$ & $2.442 * *(2.07)$ & $0.075 *(4.51)$ \\
\hline INF & $0.0016(1.65)$ & $0.0032 *(3.63)$ & $0.004 * *(2.37)$ & $0.003 *(3.62)$ \\
\hline$T D E B$ & $0.0021 * *(2.31)$ & & & \\
\hline$G O V \_E X$ & $-0.0079(-1.50)$ & & & \\
\hline DOM_GOV & & $0.0001 *(3.77)$ & & \\
\hline lDOM_GDP & & & $-2.25 * * *(1.92)$ & \\
\hline COC & & & & $-0.094 *(-6.17)$ \\
\hline \multicolumn{5}{|l|}{ Short-run estimates } \\
\hline$\triangle I D O M / D E B$ & $0.005(0.928)$ & $0.024 *(2.8)$ & $0.019 * * *(1.92)$ & $0.053^{* *}(2.3)$ \\
\hline$\triangle I G D P P C$ & $0.094 * *(2.94)$ & $0.125 *(3.06)$ & $1.699 * *(2.03)$ & $0.069 *(3.41)$ \\
\hline$\triangle I G D P P C(-1)$ & $\underline{-}$ & $\overline{-}$ & $-0.135 *(2.96)$ & 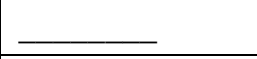 \\
\hline$\Delta I N F$ & $0.0015(1.72)$ & $0.002 * *(2.32)$ & $0.002 * *(2.64)$ & $0.001 * *(2.28)$ \\
\hline$\triangle T D E B$ & $0.002 * *(2.21)$ & 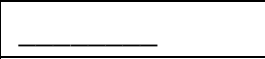 & $\overline{-}$ & 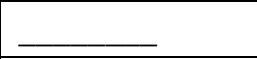 \\
\hline$\Delta I G O V_{-} E X$ & $0.0004(0.13)$ & & & \\
\hline$\Delta l G O V_{-} E X(-1)$ & $0.009 * *(2.61)$ & & & \\
\hline$\triangle D O M \_G O V$ & 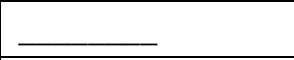 & $0.125 *(3.06)$ & & \\
\hline$\Delta I D O M \_G D P$ & $\underline{\square}$ & 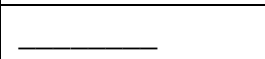 & $-1.49 * * *(1.87)$ & \\
\hline$\triangle C O C$ & 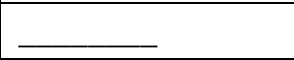 & $\underline{-}$ & 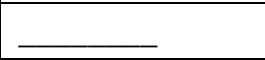 & $-0.017(-1.38)$ \\
\hline Constant & $-0.951 * *(-2.35)$ & $-0.308(-0.95)$ & $4.157(1.59)$ & $-0.463 * *(-2.24)$ \\
\hline $\operatorname{ECM}_{t}(-1)$ & $-0.909 *(-4.01)$ & $-0.996 *(-3.73)$ & $-0.663 *(-3.61)$ & $-0.919 *(-6.82)$ \\
\hline$R$-squared & 0.6402 & 0.5418 & 0.5919 & 0.8762 \\
\hline Bruesch-Godfrey & $0.341[0.56]$ & $0.352[0.55]$ & $2.028[0.15]$ & $0.004[0.94]$ \\
\hline White's test & $24[0.404]$ & $25[0.41]$ & $24[0.40]$ & $19[0.39]$ \\
\hline ARCH LM & $1.989[0.15]$ & $0.837[0.36]$ & $0.025[0.87]$ & $0.021[0.88]$ \\
\hline N. obs & 24 & 25 & 24 & 20 \\
\hline
\end{tabular}

Notes. t-statistics in parentheses. p-value in square brackets. "Denote significant at $1 \%$ level, ** at $5 \%$, and ${ }^{* * *}$ at $10 \%$.

Using the cumulative sum (CUSUM) test, the last step is to check for stability. In Figures 6, the plot of CUSUM shows that the critical values did not exceed the $5 \%$ significance level; therefore, our model is stable. 


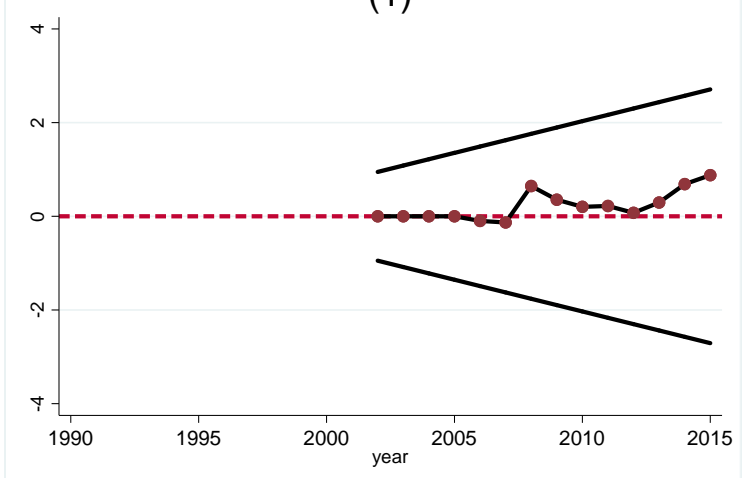

Figure 6. The plot of Cumulative Sum of Recursive Residuals for Model Stability at 5\% level of significance

The same steps have been used to analyze the results in columns 2, 3, and 4, which reports the results of the regression of three models (II, III, and IV, respectively). In all equations, the dependent variable is Top 10\%, and the independent variables are DOM/DEB, GDPPC, INF, and a set of control variables. This part of the study aims to check some hypothesis related to inequality and public debt with other control variables as well as to check the robustness of the first model.

For all regression in these three columns, the coefficients of the three main variables (DOM/DEB, GDPPC, and INF) are positive and highly significant, just as model one. The only exception is inflation in model one, which is statistically insignificant. Also, the error correction terms for all regression/models are negative and significant at the $1 \%$ level. The results further indicate that all control variables do not change the significance of the effect of domestic debt on income inequality. Therefore, this relation is not dependent on those factors.

In column 2, the control variable is an interaction term between domestic debt and government expenditure. Adding this variable to our model can help us test the following hypothesis; governments who are getting indebted to spend more on interest payments, domestic public debt, and service domestic debt will raise inequality (Salti, 2015). The results indicate that in the long-term, the coefficient on the DOM_GOV is positive and highly significant; therefore, we accept our hypothesis, as the mechanism of government spending in Lebanon leads to more inequality in income. In the short-term, the coefficient is positive but not significant.

In column 3 of Table 4, the interaction term is between domestic debt and GDP per capita. The hypothesis is that the effect of domestic public debt on income inequality depends on Lebanese income level (Salti, 2015). In the long-term, we find that the level of income in Lebanon (middle income) led to a significant and negative effect of the domestic debt on income inequality. The same results are apparent in the short run.

Column 4 presents the results from a regression, which includes a variable that measures 


\section{Al Macrothink

corruption in Lebanon (COC). The hypothesis for this regression is as follows; countries with a high index of corruption hold more domestic debt, which leads to a high level of inequality. The results show that this variable's coefficient is negative and significant in both the short and long run. Thus, corruption harms income equality. However, this variable does not change the significant positive effect of domestic debt on income inequality.

As for the error correction term (ECM (-1)), for three models, the results show that the estimated coefficients of ECM (-1) are negative and highly significant. For models II and IV, the result of these coefficients shows that at $1 \%$ significance level, $99.6 \%$ and $91.9 \%$ respectively of the divergence between the long-run and short-run dynamic is corrected within the next year. For model III, the ECM coefficient indicates that approximately $66.3 \%$ of the disequilibrium of the previous year is corrected back to the long-run equilibrium in the current year.

Just as in Model I, Table 4 reports the results of a series of the same diagnostic and stability tests. For three models, results show the absence of serial correlation, heteroscedasticity, and the Autoregressive conditional heteroscedasticity (ARCH). Using the cumulative sum (CUSUM) test, figure 7 (4, 5, and 6 are respectively for model II, III, and IV) shows that the critical values do not exceed the 5\% significance level; therefore, our models are stable.

(4)

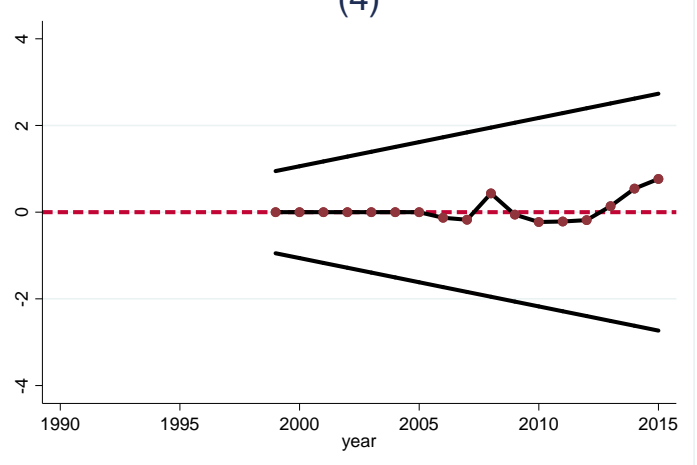

(5)

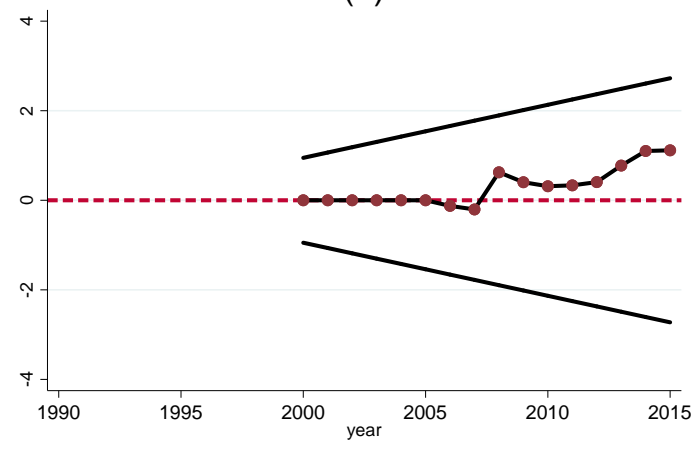

(6)

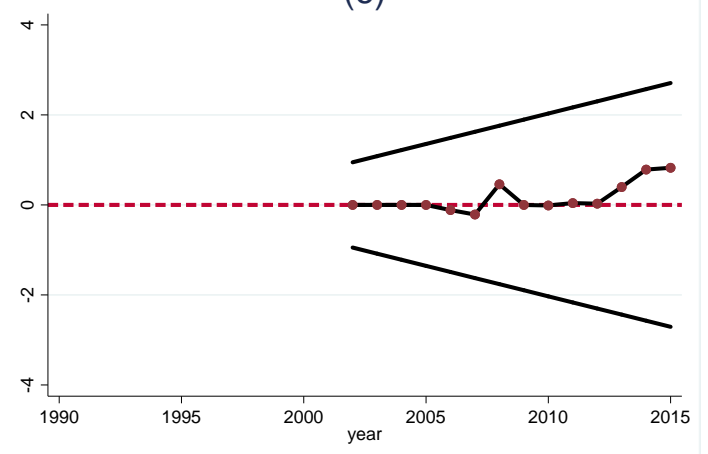

Figure 7. The plot of Cumulative Sum of Recursive Residuals for Model Stability at 5\% level of significance 


\section{Conclusion and Discussion}

In this paper, we examined the relationship between income inequality and the domestic share of the public debt in Lebanon controlling with a set of variables including GDP per capita, inflation, total debt, government expenditure, corruption, and some other interaction terms. Using time-series data covering the period 1990 - 2015, we estimated our models using the ARDL model and the ECM. Our results show that in the short and long run, and for all estimation and using different control variables, the domestic share of the public debt has a positive and significant effect on income inequality. Therefore, the more the share of domestic public debt, the more income inequality in the Lebanese economy. In the same way, economic growth in Lebanon has a positive and significant effect on income inequality. We also found that the mechanism of government spending in Lebanon leads to more inequality in income.

These results may explain some of what we covered in the first part of this study on the general picture of the reality of inequality and the public debt in Lebanon. The high volume of domestic public debt owned mostly by a few wealthy residents, especially bankers, exacerbates inequality in this country. It seems that all economic and political factors are helping to exacerbate the public debt crisis and its social repercussions. Therefore, it is important to take a series of mechanisms that may halt the negative impact of public debt on equality as well as on social stability. First, a reform of the tax system, and consequently reform it to a progressive tax system, provides a fair redistribution of income and wealth. Second, restructuring of the public debt, which helps the government reduce the ratio of the deficit to GDP. Third, it is essential to search for sources other than borrowing to cover the budget deficit, especially by revitalizing the productive sectors.

\section{References}

Abdullah, A., Doucouliagos, H., \& Manning, E. (2013). Does Education Reduce Income Inequality? A Meta-Regression Analysis. Journal of Economic Surveys, 00(0), 1-16. https://doi.org/10.1111/joes.12056

ABL. (2018). Annual report of the Association of Banks in Lebanon.

Alvaredo, F., Chancel, L., Piketty, T., Saez, E., \& Zucman, G. (2017). World Inequality Report 2018. In World Inequality Lab. https://doi.org/10.4159/9780674984769

Alvaredo, F., Chancel, L., Piketty, T., Saez, E., \& Zucman, G. (2018). Global Inequality and Policy: The Elephant Curve of Global Inequality and Growth. AEA Papers and Proceedings, 108, 103-108. https://doi.org/10.1257/pandp.20181073

Alvaredo, F., \& Piketty, T. (2014). Measuring Top Incomes and Inequality in the Middle East: Data Limitations and Illustration With the Case of Egypt. The Economic Research Forum (ERF), 832.

Alvaredo, F., Piketty, T., \& Assouad, L. (2018). Measuring Inequality in the Middle East 1990-2016: The World's Most Unequal Region?. Review of Income and Wealth, 65(4), 685-711. https://doi.org/10.1111/roiw.12385 
Arnone, M., \& Presbitero, A. F. (2006). External debt sustainability and domestic debt in Heavily Indebted Poor Countries (Issue 002).

Assouad, L. (2017). Rethinking the Lebanese economic miracle: The extreme concentration of income and wealth in Lebanon 2005-2014. WID. World Working Paper, 2017/13.

Atkinson, A. B., Piketty, T., \& Saez, E. (2011). Top Incomes in the Long Run of History. JOURNAL OF ECONOMIC LITERATURE, 49(1), 3-71. https://doi.org/10.1257/jel.49.1.3

Azzimonti, M., Francisco, E. De, \& Quadrini, V. (2012). Financial Globalization, Inequality, and the Rising Public Debt. American Economic Review, 104(8), 2267-2302. https://doi.org/10.1257/aer.104.8.2267

Bal, D. P., \& Rath, B. N. (2014). Public debt and economic growth in India : A reassessment. Economic Analysis and Policy, 44(3), 292-300. https://doi.org/10.1016/j.eap.2014.05.007

Barro, R. (2000). Inequality and Growth in a Panel of Countries. Journal of Economic Growth, 5(1), 5-32. https://doi.org/10.1016/j.jhealeco.2006.07.003

Baumstark, E. (1833). Scientific Considerations about Sovereign Credit, Sovereign Debt and Sovereign Bonds. Heidelberg: Georg Reichard.

Dawson, P. J. (1997). On testing Kuznets' economic growth hypothesis. Applied Economics Letters, 4(7), 409-410. https://doi.org/10.1080/135048597355159

Desbordes, R., \& Verardi, V. (2012). Refitting the Kuznets curve. Economics Letters, 116(2), 258-261. https://doi.org/10.1016/j.econlet.2012.03.010

Dibeh, G. (2005). The political economy of postwar reconstruction in Lebanon (No. 2005/44).

Dickey, D., \& Fuller, W. (1979). Distribution of the Estimators for Autoregressive Time Series with a Unit Root. Journal of the American Statistical Association, 74(366a), 427-431. https://doi.org/10.1080/01621459.1979.10482531

El-Laithy, H., Abu-Ismail, K., \& Hamdan, K. (2008). Poverty, Growth and Income Distribution in Lebanon (Issue August).

Forslund, K., Lima, L., \& Panizza, U. (2016). The determinants of the composition of public debt in developing and emerging market countries. Journal of Advanced Research, 1(3-4), 41-56. https://doi.org/10.1016/j.rdf.2011.09.004

Gopinath, S. (2007). Development of Local Currency Bond Markets: The Indian Experience.

Gregorio, J., \& Lee, J.-W. (2002). Education and income inequality: new evidence from cross-country data. Review of Income and Wealth, 48(3), 395-416.

https://doi.org/10.1111/1475-4991.00060

Hassine, N. (2015). Economic Inequality in the Arab Region. WORLD DEVELOPMENT, 66, 532-556. https://doi.org/10.1016/j.worlddev.2014.09.011 


\section{Macrothink Institute ${ }^{\mathrm{TM}}$}

Hauner, D. (2009). Public debt and financial development. Journal of Development Economics, 88(1), 171-183. https://doi.org/10.1016/j.jdeveco.2008.02.004

Hendrik, W. (1985). A guide to Public Sector Debt and Deficit.

IMF. (2017). IMF Executive Board Concludes Article IV Consultation with Lebanon (Issue 17/19). https://doi.org/10.5089/9781475575835.002

Jabłoński, Ł., Zmuda, P., \& Riordan, L. O. (2015). Income Inequality and Public Debt in OECD-Countries from a CSR Perspective. In New Perspectives on Corporate Social Responsibility (pp. 169-190). Springer Gabler. https://doi.org/10.1007/978-3-658-06794-6

Kripfganz, S., \& Schneider, D. C. (2016). ARDL : Stata module to estimate autoregressive distributed lag models. Stata Confrence, p. 1-20.

Kuznets, S. (1955). Economic Growth and Income Inequality. American Economic Review, 45(1), 1-28.

Kwon, R. (2016). A New Kuznetsian Dynamic: The Knowledge Economy and Income Inequality in the United States, 1917-2008. Sociological Quarterly, 57(1), 174-204.

https://doi.org/10.1111/tsq.12106

Larch, M. (2012). Fiscal Performance and Income Inequality: Are Unequal Societies More Deficit-Prone? Some Cross-Country Evidence, 65(1), 53-80.

https://doi.org/10.1111/j.1467-6435.2011.00527.x

Li, H., Xu, L. C., \& Zou, H. (2000). Corruption , Income Distribution , and Growth. Economics and Politics, 12(2), 155-181. https://doi.org/10.1111/1468-0343.00073

Michl, T. R. (1991). Debt, Deficits, and the Distribution of Income. Journal of Post Keynesian Economics, 13(3), 351-365. https://doi.org/10.1080/01603477.1991.11489854

Milanovic, B. (2016a). Global inequality: a new approach for the age of globalization. In Harvard University Press. https://doi.org/10.1007/s11127-016-0390-z

Milanovic, B. (2016b). Income inequality is cyclical. Nature, 537(7621).

https://doi.org/10.1038/537479a

Ministry of Finance. (2018). Debt and Debt Markets, A Quarterly Bulletin of the Ministry of Finance (Issues 47, Quarter IV).

MOF. (2007). The Fiscal Accounts of the Lebanese Government For the Period 1993-2006.

Nkoro, E., \& Uko, A. K. (2016). Autoregressive Distributed Lag ( ARDL ) cointegration technique : application and interpretation. Journal of Statistical and Econometric Methods, 5(4), 63-91.

Ortiz, I., \& Cummins, M. (2011). Global Inequality: Beyond the Bottom Billion - A Rapid Review of Income Distribution in 141 Countries (Issue April).

https://doi.org/10.2139/ssrn.1805046 
Panizza, U. (2008). Domestic and External Public Debt in Developing Countries. In No. 188, March 2008 (Issue 188). UNCTAD/OSG/DP/2008/3. https://doi.org/10.2139/ssrn.1147669

Pesaran, M. H., Shin, Y., \& Smith, R. J. (2001). Bounds Testing Approaches To The Analysis. Journal of Applied Econometrics, 16, 289-326. https://doi.org/10.1002/jae.616

Piketty, T. (2014). Capital in the 21st Century. In Harvard University Press. https://doi.org/10.4159/9780674369542

Piketty, T., \& Saez, E. (2003). Income Inequality in the United States, 1913-1998. The Quarterly Journal of Economics, CXVIII(1), 1-39.

https://doi.org/10.1162/00335530360535135

Piketty, T., \& Zucman, G. (2014). Capital is Back: Wealth-Income Ratios in Rich Countries 1700-2010. The Quarterly Journal of Economics, 129(3), 1255-1310.

https://doi.org/10.1093/qje/qju018

Prechel, H. (1985). The Effects of Exports, Public Debt, and Development on Income Inequality. The Sociological Quartely, 26(2), 213-234.

https://doi.org/10.1111/j.1533-8525.1985.tb00225.x

Ram, R. (1991). Kuznets's Inverted-U Hypothesis: Evidence from a Highly Developed Country. Southern Economic Journal, 57(4), 1112-1123. https://doi.org/10.2307/1060338

Ricardo, D. (1817). On the principles of political economy and taxation (Vol. 1). The Works and Correspondence of David Ricardo 1, ed. Piero Sraffa, Cambridge University Press 1951.

Riggs, J. E., Hobbs, J. C., Hobbs, G. R., \& Riggs, T. H. (2012). The Global Kuznets Curve, 1969-2007. Modern Economy, 03(02), 160-163. https://doi.org/10.4236/me.2012.32022

Saliba, E., Sayegh, W., \& Salman, T. (2017). Assessing Labor Income Inequality in Lebanon's Private Sector (Issue February).

Salti, N. (2015). Income inequality and the composition of public debt. Journal of Economics Studies, 42(5). https://doi.org/10.1108/JES-01-2014-0015

Salti, N., \& Chaaban, J. (2010). On the Poverty and Equity Implications of a Rise in the Value Added Tax. Middle East Development Journal, 2(1), 121-138.

https://doi.org/10.1142/S1793812010000174

Sanyal, P., \& Elhen, M. (2017). The Interactions of Public Debt , Income Inequality and Economic Growth for U.S. States: A Bayesian Non- Parametric Analysis. Empirical Economics Review, 7(1), 57-101.

Say, J.-B. (1821). Political Economy; Wealth . Batoche Books Kitchener. In Band II, London: Longman et al.

Sayed, A., \& Peng, B. (2020). The income inequality curve in the last 100 years: What happened to the Inverted-U? Research in Economics, 74(1), 63-72.

https://doi.org/10.1016/j.rie.2019.12.001 


\section{Macrothink}

Business and Economic Research ISSN 2162-4860 2020, Vol. 10, No. 4

Shorroks, A., Davies, J., \& Liuberas, R. (2018). Global Wealth Report 2018: the year in review (Issue October).

Smith, A. (1776). The Wealth of Nations. Random House, New Work, p. 1937.

Vasishtha, G. (2007). Domestic vs. External Borrowing and Fiscal Policy in Emerging Markets. Review of International Economics, 18(5), 1058-1074.

https://doi.org/10.1111/j.1467-9396.2010.00881.x

Wilkinson, R. G., \& Pickett, K. E. (2006). Income inequality and population health : A review and explanation of the evidence. Social Science \& Medicine, 62, 1768-1784.

https://doi.org/10.1016/j.socscimed.2005.08.036

World Bank. (2014). Inside Inequality in the Arab Republic of Egypt.

World Bank. (2016). Lebanon Promoting Poverty Reduction and Shared Prosperity.

You, J., \& Dutt, A. K. (1996). Government debt, income distribution and growth. Cambridge Journal of Economics, 20, 335-351. https://doi.org/10.1093/oxfordjournals.cje.a013619

Zhan, J. (2016). Is There a Kuznets Curve in China's Rural Area?-An Empirical Analysis on Provincial Panel Data. Modern Economy, 07(04), 391-398.

https://doi.org/10.4236/me.2016.74042

\section{Appendix}

\section{Appendix A}

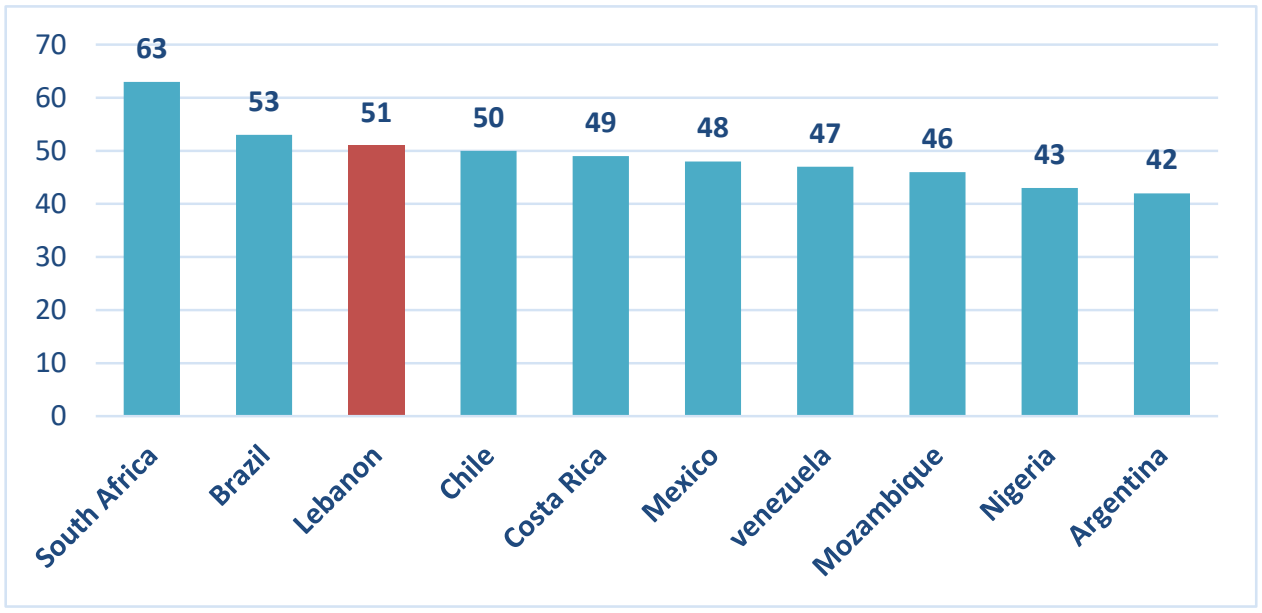

Figure A1. Gini Coefficient - The Top 10 Unequal Countries 


\section{Macrothink}

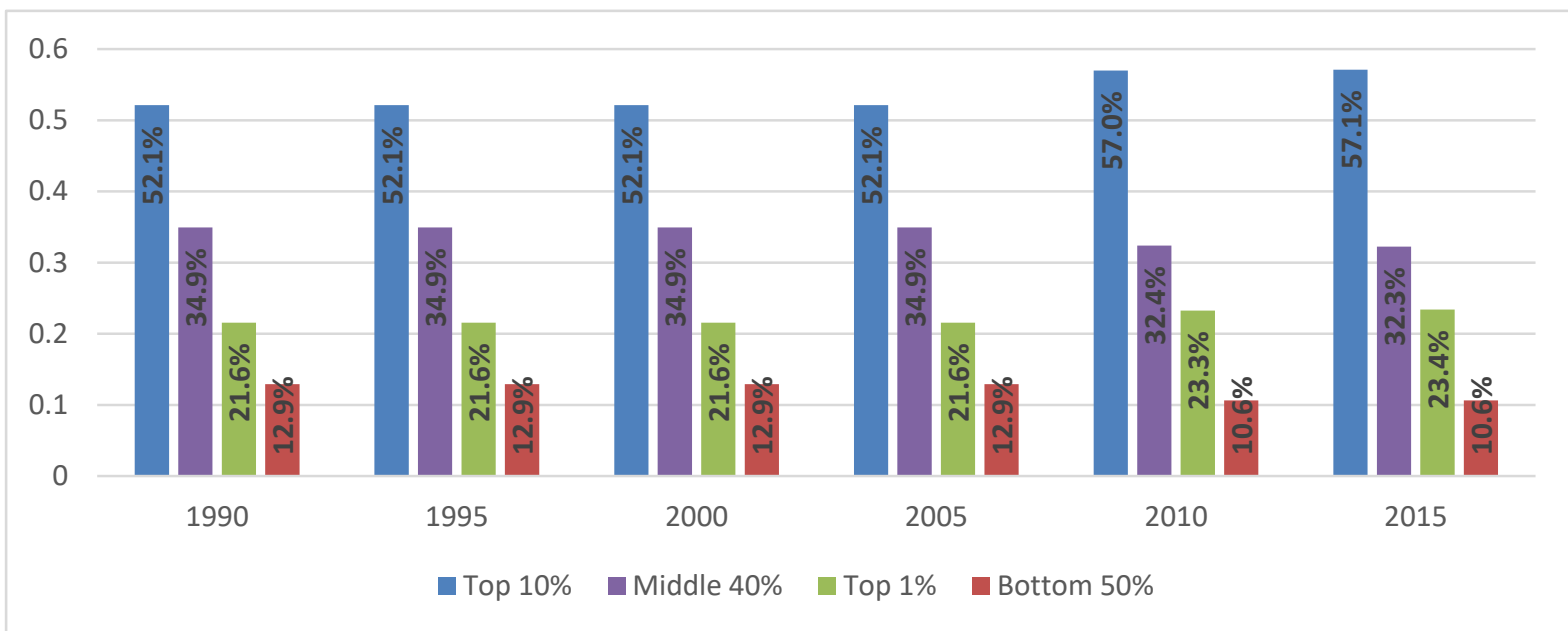

Figure A2. Income shares in Lebanon, 1990-2015

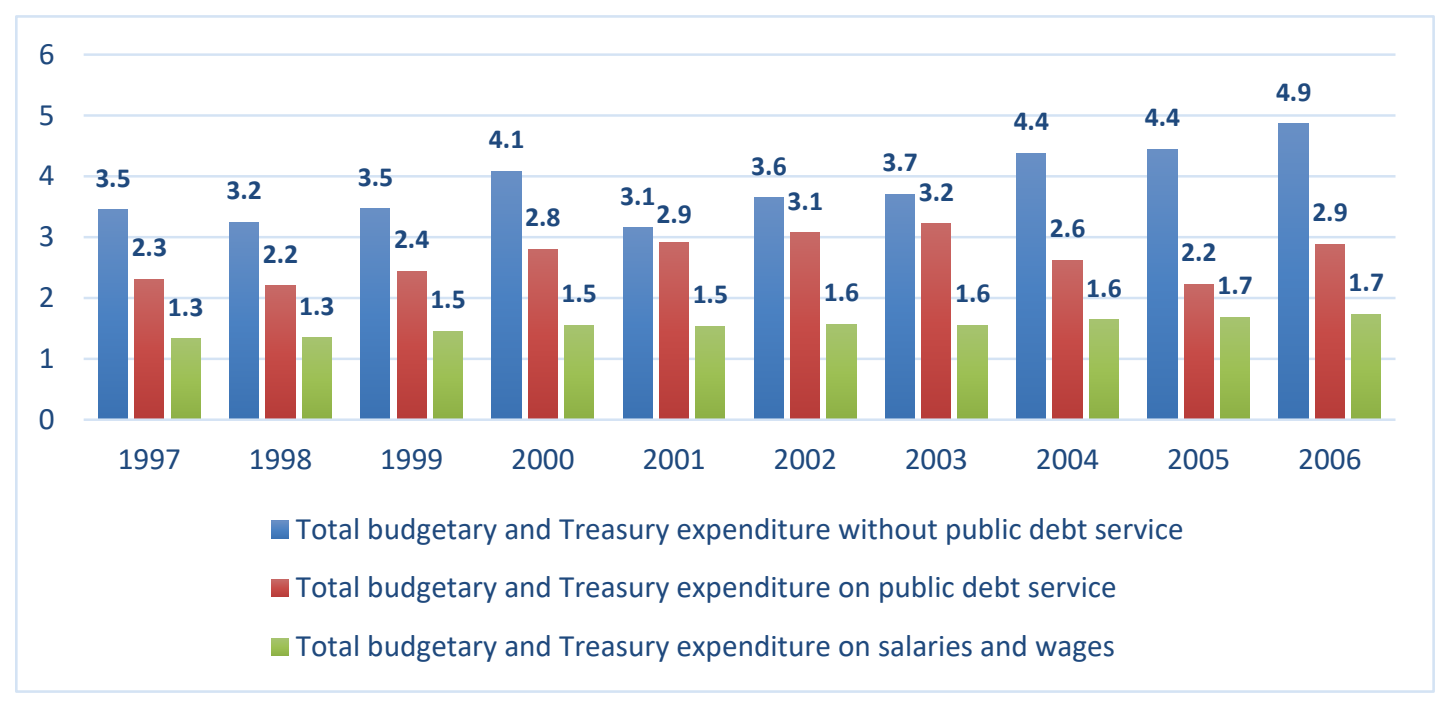

Figure A3. Total budgetary and Treasury expenditure with and without public debt service

\section{Appendix B}

The ARDL models used in this study are specified as follow:

Model (I):

$$
\begin{aligned}
& \Delta \mathrm{TOP} 10_{\mathrm{t}}=\beta_{0}+\beta_{1} \sum_{\mathrm{i}=1}^{\mathrm{p}} \mathrm{TOP}_{10} \mathrm{t}-\mathrm{i}+\beta_{2} \sum_{\mathrm{i}=0}^{\mathrm{q}_{1}} \mathrm{IDOM}_{2} \mathrm{DEB}_{\mathrm{t}-\mathrm{i}}+\beta_{3} \sum_{\mathrm{i}=0}^{\mathrm{q}_{2}} \operatorname{lgdppc}_{\mathrm{t}-\mathrm{i}}+ \\
& \beta_{4} \sum_{\mathrm{i}=0}^{\mathrm{q}_{3}} \mathrm{TDEB}_{\mathrm{t}-\mathrm{i}}+\beta_{5} \sum_{\mathrm{i}=0}^{\mathrm{q}_{4}} \mathrm{GOV}_{-} \mathrm{EX}_{\mathrm{t}-\mathrm{i}}+\beta_{6} \sum_{\mathrm{i}=0}^{\mathrm{q}_{5}} \mathrm{INF}_{\mathrm{t}-\mathrm{i}}+\sum_{\mathrm{i}=1}^{\mathrm{p}} \gamma_{\mathrm{i}}^{\mathrm{I}} \Delta \mathrm{TOP} 10_{\mathrm{t}-\mathrm{i}}+ \\
& \sum_{\mathrm{i}=1}^{\mathrm{q}} \gamma_{\mathrm{i}}^{\mathrm{D}} \Delta \mathrm{IDOM} \mathrm{DEB}_{\mathrm{t}-\mathrm{i}}+\sum_{\mathrm{i}=1}^{\mathrm{q}} \gamma_{\mathrm{i}}^{\mathrm{G}} \Delta \operatorname{lgdppc}_{\mathrm{t}-\mathrm{i}}+\sum_{\mathrm{i}=0}^{\mathrm{q}} \gamma_{\mathrm{i}}^{\mathrm{T}} \Delta \mathrm{TDEB}_{\mathrm{t}-\mathrm{i}}+ \\
& \sum_{\mathrm{i}=0}^{\mathrm{q}} \gamma_{\mathrm{i}}^{\mathrm{GO}} \Delta \mathrm{GOV}_{-} \mathrm{EX}_{\mathrm{t}-\mathrm{i}}+\sum_{\mathrm{i}=0}^{\mathrm{q}} \gamma_{\mathrm{i}}^{\mathrm{IF}} \Delta \mathrm{INF}_{\mathrm{t}-\mathrm{i}}+\delta \mathrm{ECM}_{\mathrm{t}-1}+\varepsilon_{\mathrm{t}}
\end{aligned}
$$


Model (II):

$$
\begin{gathered}
\Delta \text { TOP } 10_{\mathrm{t}}=\beta_{0}+\beta_{1} \sum_{\mathrm{i}=1}^{\mathrm{p}}{\text { TOP } 10_{\mathrm{t}-\mathrm{i}}+\beta_{2} \sum_{\mathrm{i}=0}^{\mathrm{q}_{1}} \operatorname{lDOM}_{\text {DEEB }}+\mathrm{i}}+\beta_{3} \sum_{\mathrm{i}=0}^{\mathrm{q}_{2}} \operatorname{lgdppc}_{\mathrm{t}-\mathrm{i}}+ \\
\beta_{4} \sum_{\mathrm{i}=0}^{\mathrm{q}_{3}} \text { Dom_gov }_{\mathrm{t}-\mathrm{i}}+\beta_{5} \sum_{\mathrm{i}=0}^{\mathrm{q}_{4}} \mathrm{INF}_{\mathrm{t}-\mathrm{i}}+\sum_{\mathrm{i}=1}^{\mathrm{p}} \gamma_{\mathrm{i}}^{\mathrm{I}} \Delta \mathrm{TOP} 10_{\mathrm{t}-\mathrm{i}}+\sum_{\mathrm{i}=1}^{\mathrm{q}} \gamma_{\mathrm{i}}^{\mathrm{D}} \Delta \mathrm{IDOM} \mathrm{DEB}_{\mathrm{t}-\mathrm{i}}+ \\
\sum_{\mathrm{i}=1}^{\mathrm{q}} \gamma_{\mathrm{i}}^{\mathrm{G}} \Delta \operatorname{lgdppc}_{\mathrm{t}-\mathrm{i}}+\sum_{\mathrm{i}=0}^{\mathrm{q}} \gamma_{\mathrm{i}}^{\mathrm{DG}} \Delta \text { Dom }_{-} \operatorname{gov}_{\mathrm{t}-\mathrm{i}}+\sum_{\mathrm{i}=0}^{\mathrm{q}} \gamma_{\mathrm{i}}^{\mathrm{IF}} \Delta \mathrm{INF}_{\mathrm{t}-\mathrm{i}}+\delta \mathrm{ECM}_{\mathrm{t}-1}+\varepsilon_{\mathrm{t}}
\end{gathered}
$$

Model (III):

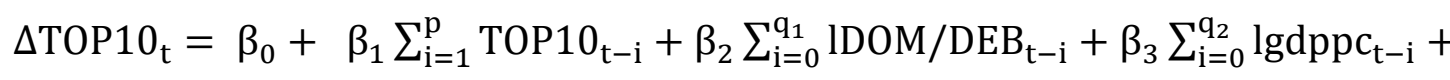

$$
\begin{aligned}
& \beta_{4} \sum_{\mathrm{i}=0}^{\mathrm{q}_{3}} \operatorname{ldom}_{-} \text {gdp } \mathrm{t}_{\mathrm{t}-\mathrm{i}}+\beta_{5} \sum_{\mathrm{i}=0}^{\mathrm{q}_{4}} \mathrm{INF}_{\mathrm{t}-\mathrm{i}}+\sum_{\mathrm{i}=1}^{\mathrm{p}} \gamma_{\mathrm{i}}^{\mathrm{I}} \Delta \mathrm{TOP} 10_{\mathrm{t}-\mathrm{i}}+\sum_{\mathrm{i}=1}^{\mathrm{q}} \gamma_{\mathrm{i}}^{\mathrm{D}} \Delta \mathrm{lDOM} / \mathrm{DEB}_{\mathrm{t}-\mathrm{i}}+ \\
& \sum_{\mathrm{i}=1}^{\mathrm{q}} \gamma_{\mathrm{i}}^{\mathrm{G}} \Delta \operatorname{lgdpp} c_{\mathrm{t}-\mathrm{i}}+\sum_{\mathrm{i}=0}^{\mathrm{q}} \gamma_{\mathrm{i}}^{\mathrm{DG}} \Delta \operatorname{ldom}_{-} \mathrm{gdp} \mathrm{p}_{\mathrm{t}-\mathrm{i}}+\sum_{\mathrm{i}=0}^{\mathrm{q}} \gamma_{\mathrm{i}}^{\mathrm{IF}} \Delta \mathrm{INF}_{\mathrm{t}-\mathrm{i}}+\delta \mathrm{ECM}_{\mathrm{t}-1}+\varepsilon_{\mathrm{t}}
\end{aligned}
$$

Model (IV):

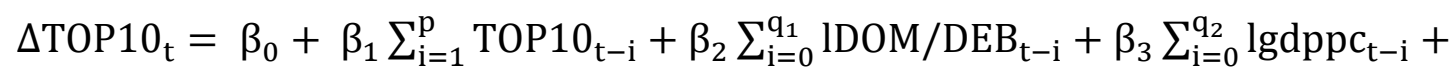

$$
\begin{aligned}
& \beta_{4} \sum_{\mathrm{i}=0}^{\mathrm{q}_{3}} \mathrm{COC}_{\mathrm{t}-\mathrm{i}}+\beta_{5} \sum_{\mathrm{i}=0}^{\mathrm{q}_{4}} \mathrm{INF}_{\mathrm{t}-\mathrm{i}}+\sum_{\mathrm{i}=1}^{\mathrm{p}} \gamma_{\mathrm{i}}^{\mathrm{I}} \Delta \mathrm{TOP} 10_{\mathrm{t}-\mathrm{i}}+\sum_{\mathrm{i}=1}^{\mathrm{q}} \gamma_{\mathrm{i}}^{\mathrm{D}} \Delta \mathrm{IDOM} / \mathrm{DEB}_{\mathrm{t}-\mathrm{i}}+ \\
& \sum_{\mathrm{i}=1}^{\mathrm{q}} \gamma_{\mathrm{i}}^{\mathrm{G}} \Delta \operatorname{lgdppc_{\mathrm {t}-\mathrm {i}}}+\sum_{\mathrm{i}=0}^{\mathrm{q}} \gamma_{\mathrm{i}}^{\mathrm{DG}} \Delta \mathrm{COC}_{\mathrm{t}-\mathrm{i}}+\sum_{\mathrm{i}=0}^{\mathrm{q}} \gamma_{\mathrm{i}}^{\mathrm{IF}} \Delta \mathrm{INF}_{\mathrm{t}-\mathrm{i}}+\delta \mathrm{ECM}_{\mathrm{t}-1}+\varepsilon_{\mathrm{t}}
\end{aligned}
$$

\section{Copyrights}

Copyright for this article is retained by the author(s), with first publication rights granted to the journal.

This is an open-access article distributed under the terms and conditions of the Creative Commons Attribution license (http://creativecommons.org/licenses/by/4.0/) 